\title{
Genetic Structure and Phylogenetic Relationships of Capsicum chinense
}

\author{
Marissa Moses and Pathmanathan Umaharan ${ }^{1}$ \\ Department of Life Sciences, Faculty of Science and Agriculture, University of the West Indies, St. \\ Augustine, Trinidad and Tobago, West Indies
}

AdDitional INDEX words. RAPD, Caribbean, Neotropics, diversity, hot pepper, domestication, dispersion

\begin{abstract}
Capsicum chinense is commercially the most important pepper species grown in the Caribbean. It is popularly used to impart pungency and flavor to Caribbean cuisine. However, unlike Capsicum annuum, which is the most commercially exploited domesticated species internationally, $C$. chinense has not been methodically collected or characterized for systematic improvement through plant breeding. The objectives of the study were to assess the diversity of $C$. chinense and its structure within the Caribbean basin and to determine its phylogenetic relationship to groups within South America. DNA isolated from 201 accessions of $C$. chinense, representing geographical regions where the species is found, were amplified using arbitrary primers to generate 138 polymorphic and reproducible random amplification of polymorphic DNA (RAPD) markers. Nei's and Shannon's diversity indices for C. chinense (0.28 and 0.419, respectively) were higher in South America compared with Central America or the Caribbean, corresponding to its putative center of diversity. The study showed the existence of three phylogenetic clusters within $C$. chinense. The largest cluster consisted of accessions from the Upper Amazon region, the Guianas including Venezuela, and the Lesser Antilles of the Caribbean. The other major cluster was represented by accessions principally from the Lower Amazon region. Another distinct but small cluster consisted of samples solely from the Greater Antilles of the Caribbean. The discovery of the three phylogenetic clusters within $C$. chinense may have potential for exploiting heterosis in breeding. The implications of the findings to the understanding of the phylogenetic origin and distribution of $C$. chinense are discussed.
\end{abstract}

Capsicum peppers are popularly grown around the world as a pungent condiment. The genus name Capsicum is believed to have been derived from the Greek word capsicon, which in turn was derived from the Latin root kapetin, which means "to bite" in reference to the fruit's pungency (Weiss, 2002). Capsicum (Solanaceae family) consists of 33 accepted wild species and five domesticated species (U.S. Department of Agriculture, 2012): C. annuum (chile and sweet pepper types), C. chinense (habanero types), C. frutescens (tabasco types), C. pubescens (rocoto pepper), and C. baccatum (aji or peruvian pepper). Capsicum species originated in the Neotropics, which extends from southern Mexico through Central America and northern South America to southern Brazil (Pickersgill, 1971), although it is popularly grown and consumed in many parts of the world. C. chinense is of Amazonian origin and is indigenous to South America and the Caribbean (Eshbaugh, 1993; Heiser, 1976).

Although $C$. annuum is economically the most important worldwide, market surveys indicate that West Indian C. chinense cultivars such as Scotch Bonnet and West Indies Red sell for a premium price in European and North American markets (Cooper et al., 1993). The popularity of the latter has been attributed to its high pungency and distinct flavor profile. Furthermore, the migration of Caribbean people to metropolitan countries around the world, taking with them their unique cultures and cuisines, has created niche markets for C. chinense, commonly referred to as ethnic markets.

Despite its importance, productivity of $C$. chinense [10 to $20 \mathrm{Mg} \cdot \mathrm{ha}^{-1}$ (Stewart, 2003)] is low in the Caribbean compared with reported yields for C. annuиm [30 to $60 \mathrm{Mg} \cdot \mathrm{ha}^{-1}$ (Garcia

Received for publication 3 May 2011. Accepted for publication 7 June 2012. Special thanks are extended to Verena Gajardarsingh, Nigel Austin, Herman Adams, Antonio DeGannes, and the staff of the University of the West Indies greenhouses for professional assistance, training, and advice.

${ }^{1}$ Corresponding author. E-mail: Pathmanathan.Umaharan@sta.uwi.edu. et al., 2002)]. Chief among the reasons for low yield are the use of uncharacterized landraces by farmers in the Caribbean. In contrast, $C$. annuиm has undergone extensive breeding throughout the world with numerous high-yielding cultivars including hybrids available in the market (Geleta and Labuschagne, 2004; Geleta et al., 2004; Hari et al., 2005; Hundal and Dhall, 2005; Khalil et al., 2002; Patel et al., 2004). Heterosis breeding has been popularly used to improve yields in $C$. annuum, where fruit yield, earliness, and plant height have all shown significant heterosis. However, heterosis breeding requires a thorough understanding of the structure of diversity and the level of heterosis that can be derived for agronomically important traits by intercrossing distinct phylogenetic groups.

During the past decade, molecular markers have been used to distinguish among Capsicum species or cultigroups (Baral and Bosland, 2004; Toquica et al., 2003), resolve taxonomic uncertainties (Rodriguez et al., 1999; Toquica et al., 2003), and to assess the genetic diversity in selected populations or germplasm collections (Baral and Bosland, 2002; Buso et al., 2003; Hernandez-Verdugo et al., 2001; Lanteri et al., 2003; Rodriguez et al., 1999; Votava et al., 2005).

Early studies investigating genetic diversity in the genus (wild and domesticated species) used protein- or allozymebased molecular markers (Loaiza-Figueroa et al., 1989; Panda et al., 1986). These were subsequently replaced by DNA-based molecular markers such as restriction fragment length polymorphism [RFLP (Lefebvre et al., 1993; Prince et al., 1995)], RAPD (Baral and Bosland, 2002, 2004; Buso et al., 2003; Kang et al., 1997; Prince et al., 1995; Rodriguez et al., 1999; Votava and Bosland, 2001; Votava et al., 2005), and amplified fragment length polymorphism [AFLP (Guzmán et al., 2005; Lanteri et al., 2003; Paran et al., 1998; Toquica et al., 2003)].

Primers to amplify 46 microsatellite loci were reported (Lee et al., 2004) using an interspecific cross between C. annuum 
'TF68' (Seminis Korea, Seoul, South Korea) and C. chinense (cultivar Habanero). Additional microsatellites have been described in interspecific linkage maps (Yi et al., 2006). Microsatellites have been found to be highly variable and codominant; therefore, their information value is high compared with other markers such as RFLPs, AFLPs, and RAPDs. Microsatellites were not used in this study as a result of their unavailability at the time of this work.

The objectives of this study were therefore to use RAPDbased markers to determine the genetic structure within accessions sampled and to estimate the diversity within the groups identified.

\section{Materials and Methods}

Germplasm COllection AND ESTABLiShMent. A total of 201 accessions of $C$. chinense from the University of the West Indies germplasm collection were used in this study (Table 1). These accessions were grouped into (or represent germplasm originally obtained from) seven geographical areas: Trinidad and Tobago (79), Greater Antilles (14), Lesser Antilles (19), Central America (11), Upper Amazon (24), Lower Amazon (28), and Guianas including Venezuela (26). For the purposes of this study, the Greater Antilles refers to Caribbean islands such as Jamaica, Cuba, Puerto Rico, and the Bahamas, whereas the Lesser Antilles comprises islands such as Barbados, St. Lucia, and Guadeloupe. In addition, three accessions each of C. annuum and C. baccatum were included as outgroups in the study for rooting of dendrograms.

MorPhological CHARACTERIZATION. Accessions were characterized for taxonomic characteristics as outlined in the taxonomic key (International Plant Genetic Resources Institute, 1983). These characteristics included for instance the number of flowers per node, flower position, flower color, and the presence of an annular constriction on the peduncle (Table 1). These characters were used to confirm the species identity of the putative $C$. chinense accessions in the collection.

DNA EXTRACTION, POLYMERASE CHAIN REACTION CONDITIONS, AND RANDOM AMPLIFIED POLYMORPHIC DNA BAND SCORING. A sample of $3 \mathrm{~g}$ leaf material per accession was pulverized in liquid nitrogen and DNA extracted using a standard protocol (Prince et al., 1997). Extracted DNA was purified using RNase digestion, phenol-chloroform extraction, and isopropanol precipitation (Sambrook and Russell, 2001) and stored in $50 \mu \mathrm{L}$ of $10 \mathrm{~mm}$ Tris, $1 \mathrm{~mm}$ ethylenediaminetetraacetic acid at $-20{ }^{\circ} \mathrm{C}$.

Each $25-\mu \mathrm{L}$ polymerase chain reaction (PCR) consisted of $20 \mathrm{ng}$ template DNA, $2 \mathrm{~mm} \mathrm{MgCl}_{2}, 10 \times$ reaction buffer, $0.2 \mathrm{~mm}$ mixed deoxyribonucleotides, $50 \mathrm{pM}$ of a decanucleotide primer, and 0.5 unit Klentaq (DNA Polymerase Technology, St. Louis, MO). A Techne PHC-3 thermal cycler (Bibby Scientific, Burlington, NJ) was used for all PCR amplifications. The thermal cycling parameters were derived from a related research study (Rodriguez et al., 1999). After an initial denaturation step of two cycles at $91{ }^{\circ} \mathrm{C}$ for $60 \mathrm{~s}, 42{ }^{\circ} \mathrm{C}$ for $15 \mathrm{~s}$, and $72{ }^{\circ} \mathrm{C}$ for $70 \mathrm{~s}, 38$ cycles were performed at $91{ }^{\circ} \mathrm{C}$ for $15 \mathrm{~s}$, $42{ }^{\circ} \mathrm{C}$ for $20 \mathrm{~s}$, and $72{ }^{\circ} \mathrm{C}$ for $20 \mathrm{~s}$ with a final extension step of $72{ }^{\circ} \mathrm{C}$ for $4 \mathrm{~min}$.

Twenty-five primers (Operon Technologies, Alameda, CA) as used by Rodriguez et al. (1999) were screened to identify those primers that were both highly polymorphic and produced bright and distinct bands. Nine primers, OPR12, OPAO18,
OPAX1, OPAU3, OPAK10, OPAB4, OPAB19, OPK16, and OPAI2, were selected. DNA from the $C$. chinense accession TT-40 was used as a positive control in all amplifications and subsequent gel electrophoresis runs. A negative control was also included as part of each amplification. The PCR products were tested for their repeatability over time, and only reproducible bands were scored.

Amplified samples $(15 \mu \mathrm{L})$, along with a 1-kb ladder (Invitrogen; Life Technologies Corp., Carlsbad, CA), were subjected to gel electrophoresis at $5 \mathrm{~V} / \mathrm{cm}$ on a $1.2 \%$ agarose gel containing ethidium bromide. The DNA was visualized on an ultraviolet transilluminator (UVP, Upland, CA) and photodocumented using a gel documentation system (Imagestore 7500; UVP). The presence or absence of the reproducible RAPD markers generated for each accession was given a score of 1 or 0 , respectively.

Data AnAlysis. A non-metric multidimensional scaling (MDS) plot using Dice's similarity index of all accessions was drawn with PAST Version 1.78 (Hammer et al., 2001). Cluster analysis was performed to determine the number of distinct clusters using statistical software (NCSS Version 07.1.19; NCSS, Kaysville, UT). The clusters were revealed on the MDS plot. Analysis of molecular variance (AMOVA) was carried out in ARLEQUIN Version 3.11 (Excoffier et al., 2005) to test the significance of differences between the phylogenetic clusters as well as geographic regions within Latin America and the Caribbean. The significance of phylogeographical groups (geographically distinct groups of accessions falling within a phylogenetic group) discerned within each phylogenetic cluster was also tested using AMOVA. Unweighted pair group method with arithmetic mean dendrograms were drawn based on the Fixation index values of geographic regions and phylogeographic groupings. The presence of unique RAPD markers was also noted for the geographic regions, phylogeographic groups, and phylogenetic clusters within $C$. chinense. POPGENE Version 1.31 (Yeh and Boyle, 1997) was used to calculate three indices of diversity (i.e., Nei's diversity index, Shannon's index, and percentage of polymorphic loci).

\section{Results}

The nine arbitrary primers used generated 138 reproducible, polymorphic bands (Fig. 1). The number of polymorphic bands generated varied from nine to 20 depending on the primer with an average of 15.2 bands per primer.

Diversity of C. Chinense. Both Nei's and Shannon's diversity indices for the geographical regions within Latin America and the Caribbean (Table 2) mirrored each other in order of magnitude, whereas percentage polymorphic loci showed minor deviations from the former two measures. In general, the diversity indices were higher for the Upper and Lower Amazon regions than for the Caribbean or Central American groups.

Phylogenetic structure within $\boldsymbol{C}$. Chinense. The accessions of $C$. chinense fell into three phylogenetic clusters (i.e., A, $\mathrm{B}$, and C) based on the MDS plot (Fig. 2) and cluster analysis (data not shown), which was supported by AMOVA $(P<0.05)$ (Table 3)

Accessions from the Upper Amazon, Central America, Lesser Antilles, and Trinidad and Tobago fell solely or predominantly 


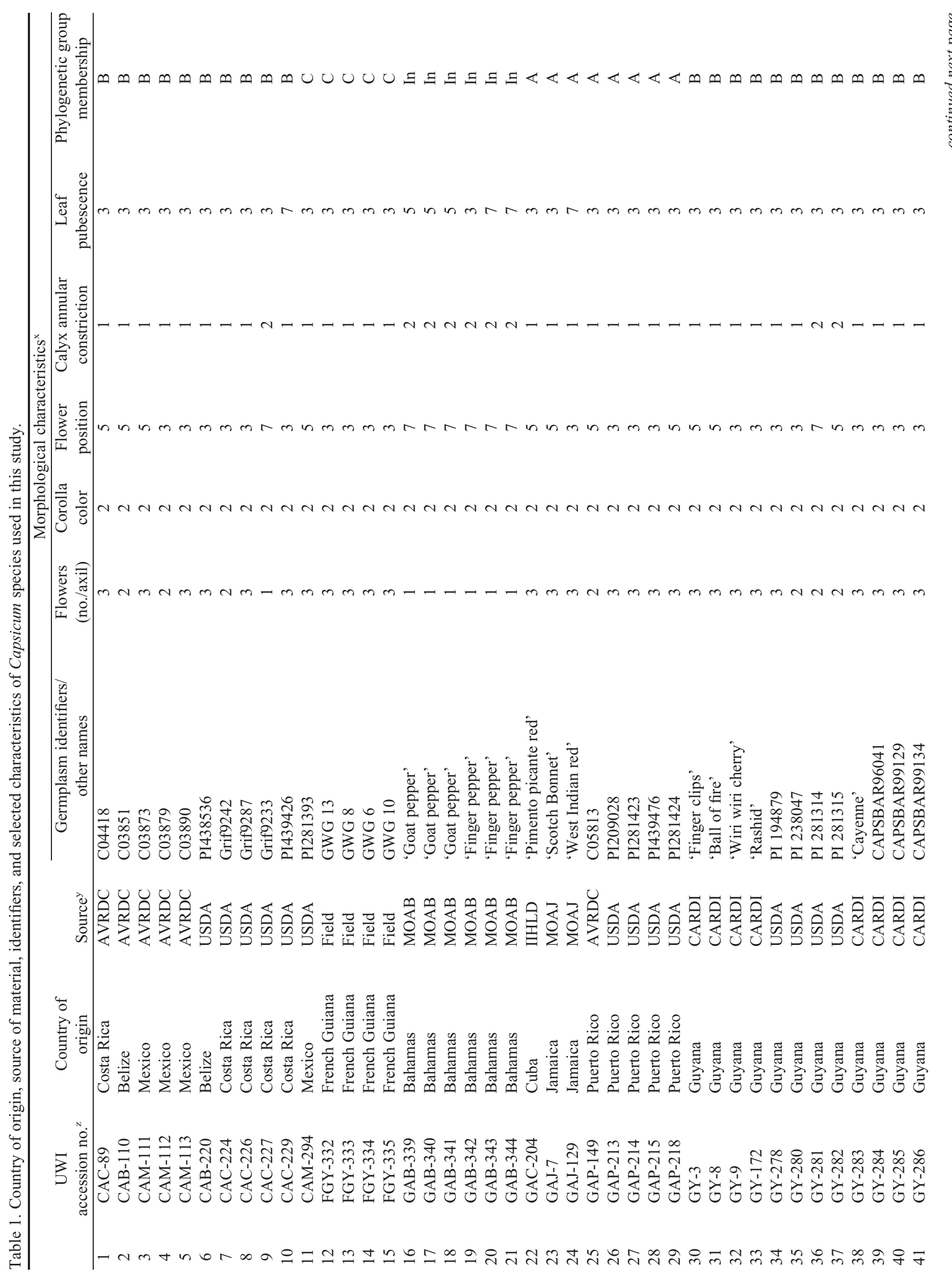




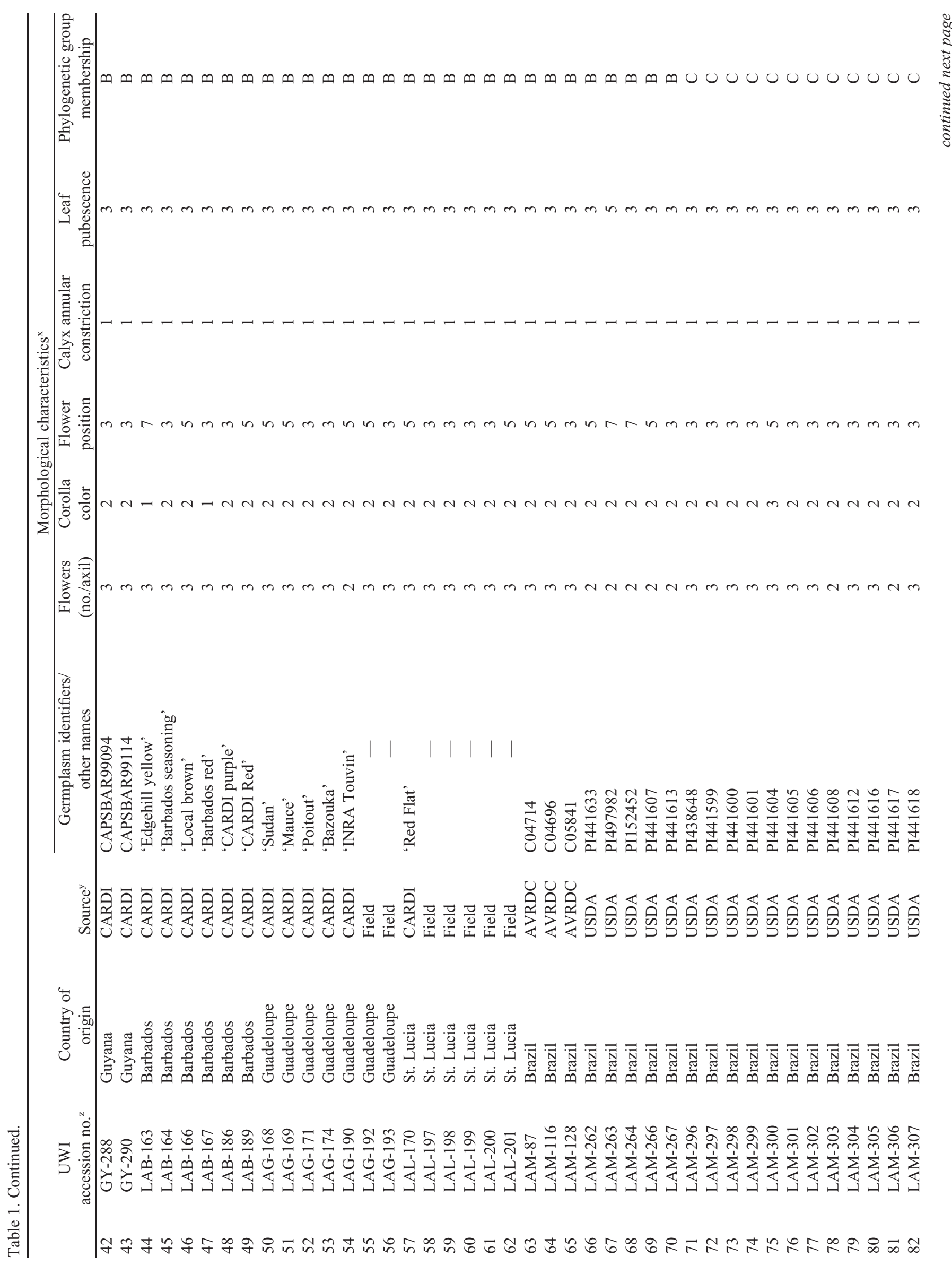




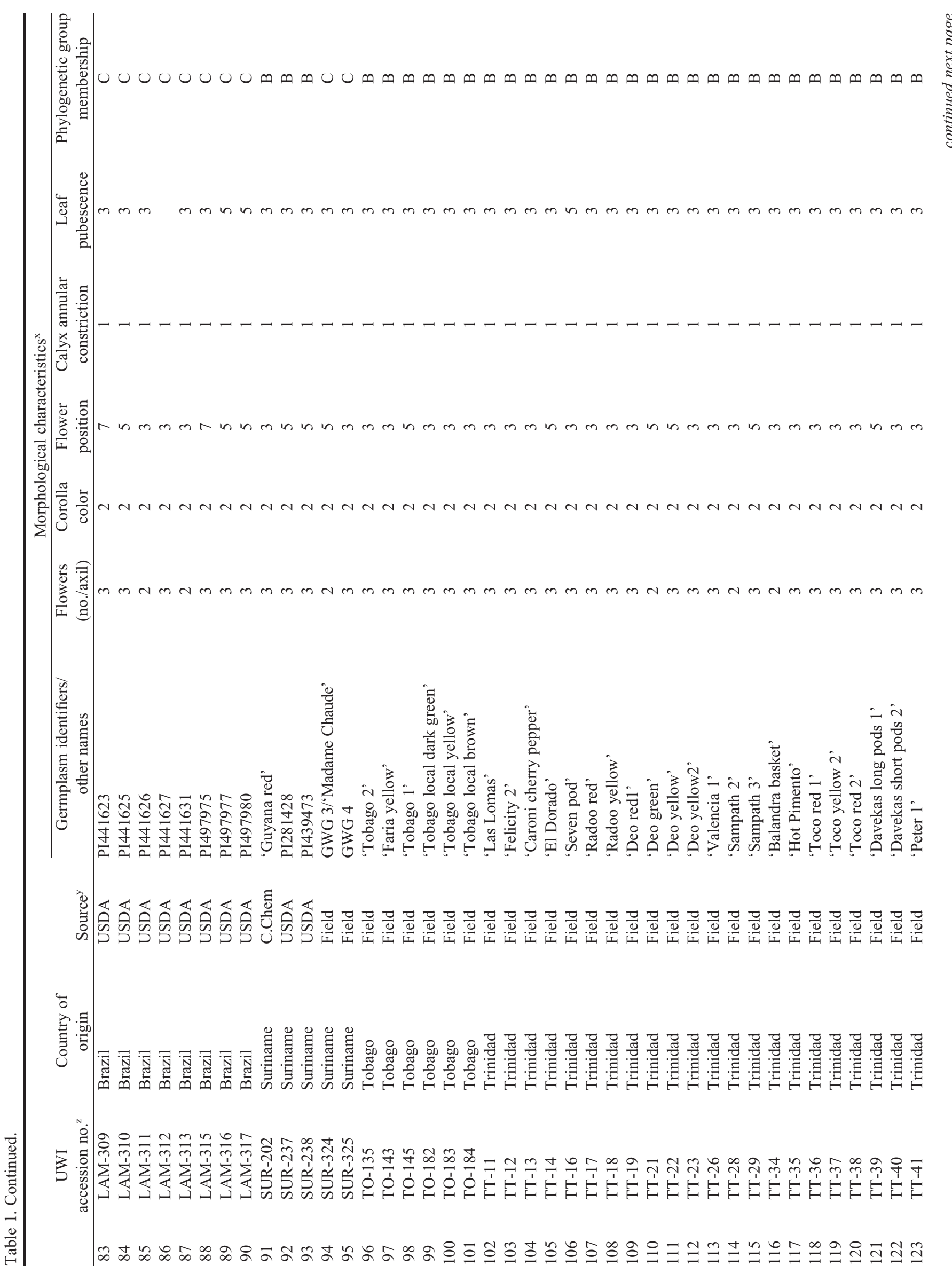




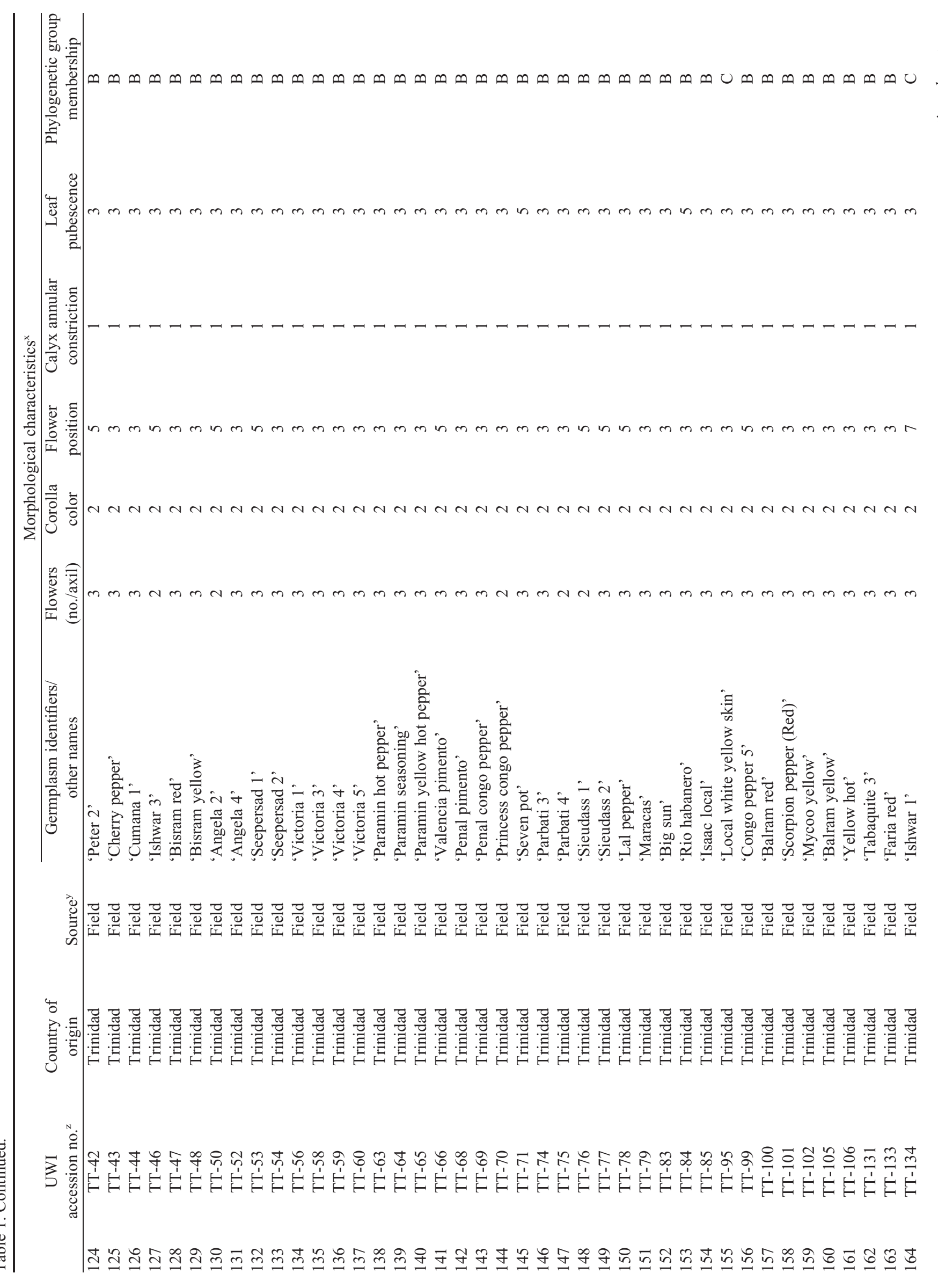




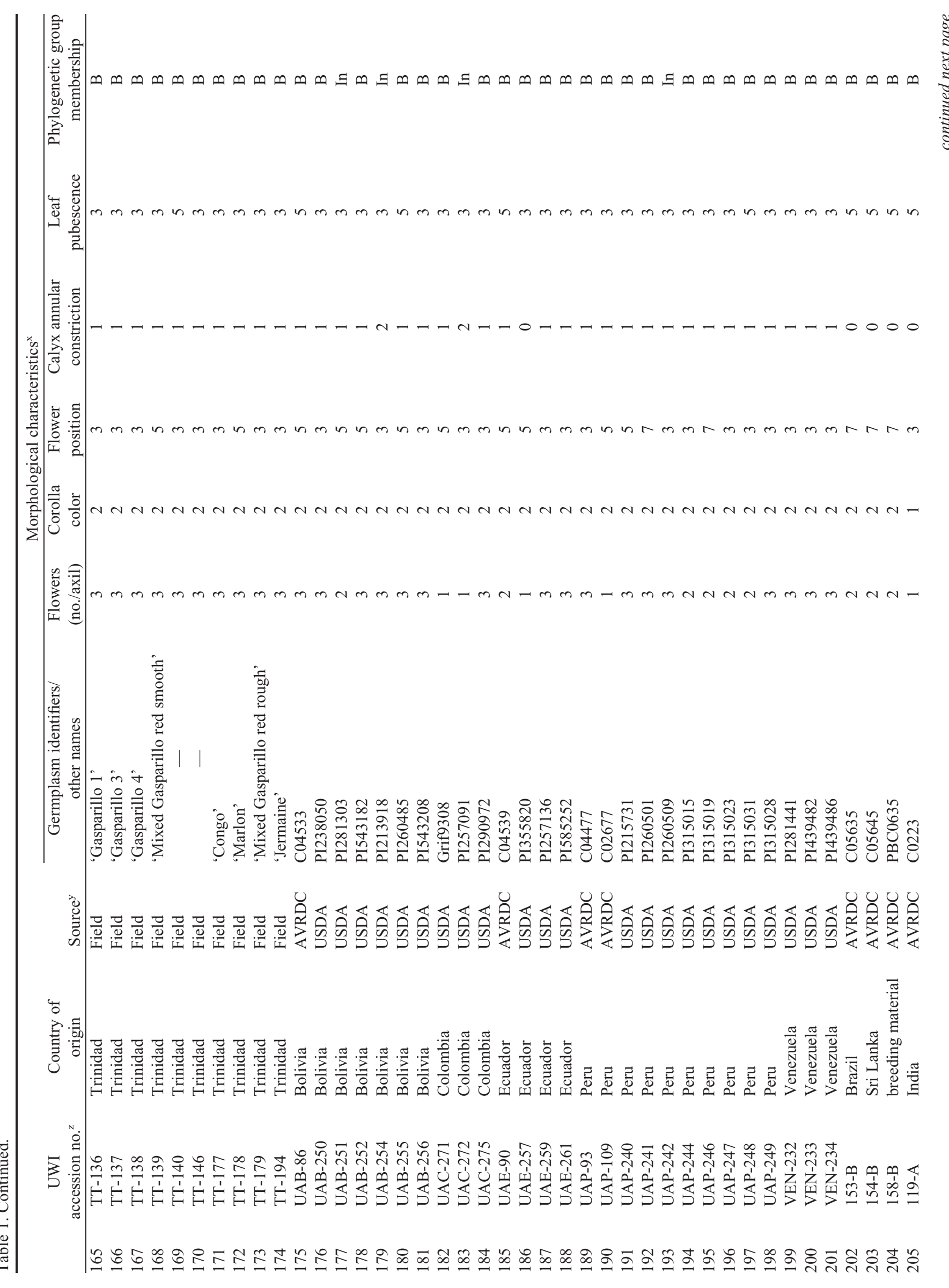




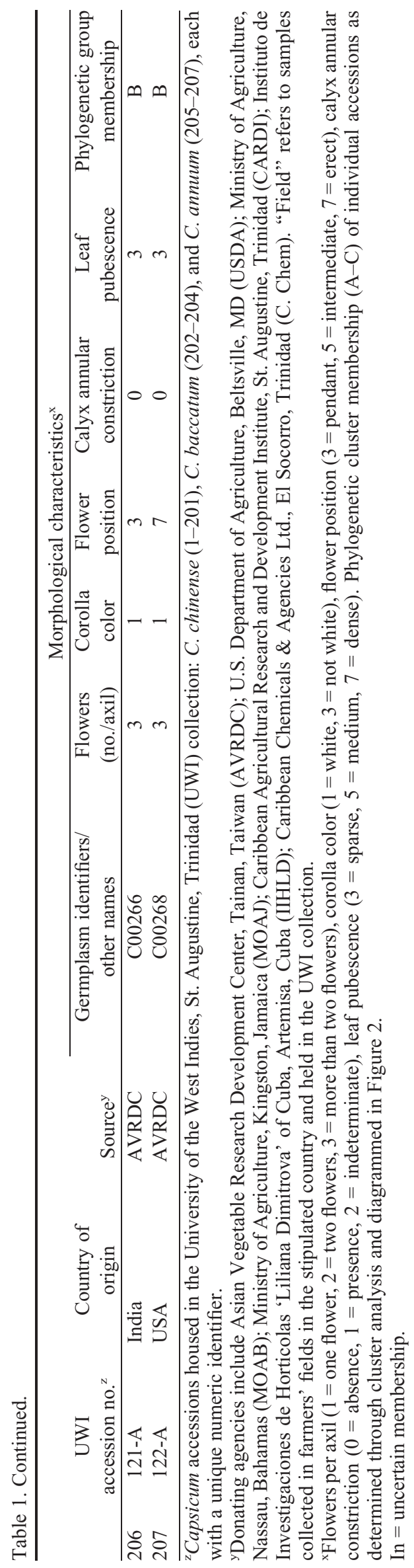

into Cluster B, whereas accessions from the Lower Amazon fell predominantly (71\%) into Cluster C and the remainder (29\%) in Cluster B. The situation was reversed in the Guianas including Venezuela, where most accessions (77\%) fell into Cluster B with a minority falling (23\%) into Group C. Accessions from the Greater Antilles fell into a unique Cluster A (60\%) with the remainder falling into an outgroup.

DiVERSITY WITHIN THE PHYLOGEOGRAPHIC GROUPS. Accessions from the geographic regions that fell into the three phylogenetic clusters (A, B, and $\mathrm{C}$ ) formed nine subgroups herein referred to as phylogeographic groups (Table 4). The most diverse phylogeographic group with regard to all three diversity indices was the Lower Amazon accessions that fell into phylogenetic Cluster $\mathrm{C}$ followed by the Upper Amazon accessions that fell into phylogenetic Cluster B. Among those regions belonging to phylogenetic Cluster $\mathrm{B}$, the greatest diversity estimated by the indices was in the Upper Amazon followed by Central America, Guianas including Venezuela, Trinidad and Tobago, and Lesser Antilles in that order.

STRUCTURE WITHIN PHYLOGEOGRAPHIC GROUPS WITHIN PHYLOGENETIC CLUSTERs. An AMOVA conducted between phylogeographic groups within each phylogenetic cluster indicated that there was some underlying structure within phylogenetic Clusters B and C (data not shown) at $(P<0.05)$. However, the structure was relatively weak, suggested by the low percentage $(8 \%)$ of the total variation being attributed to between-population variation.

Phylogenetic Relationship among Regions AND groups. The dendrogram (Fig. 3A) generated for the various geographic regions indicated that accessions from Central America, Guianas including Venezuela, Upper Amazon, Trinidad and Tobago, and Lesser Antilles were more similar among each other than to Lower Amazon or to the Greater Antilles. The dendrogram of phylogeographic groups (Fig. 3B) was similar to that generated for geographic regions. The phylogeographic groups belonging to Cluster A (Greater Antilles) were more similar to Cluster $\mathrm{C}$ (Lower Amazon and a few accessions from the Guianas) than those belonging to Cluster B (Central America, Guianas including Venezuela, Upper Amazon, Trinidad and Tobago, and Lesser Antilles).

Molecular characterization of the Phylogenetic CLUSTERS. From 11 discriminatory markers (RAPD bands) accounting for the variation among the three phylogenetic groups, eight markers were monomorphic in phylogenetic Cluster A, two in Cluster C, and one in Cluster B (data not presented).

\section{Discussion}

The Phylogenetic STRuCture of $C$. ChineNSE. This study for the first time recognized three phylogenetic clusters within C. chinense in the Latin America and the Caribbean regions. Two of the Clusters (B and C) were widespread throughout this region, whereas one (Cluster A) was specific to the Greater Antilles region of the Caribbean. Cluster B, which had its greatest diversity in the Upper Amazon region according to diversity estimates (Tables 2 and 4), was the most geographically diverse and predominant group, extending from Central America in the north to the Guianas, Venezuela, Trinidad, and the Lesser Antilles to the east. There was also evidence of substructures within Clusters B and C based on geography (phylogeographic groups), but the substructures were weak and accounted for only $8 \%$ of the total variation, indicating that 
sufficient geographical isolation may not have existed postdomestication of $C$. chinense in the Americas.

Similar clustering based on geography was observed in the genetic structure of $C$. baccatum, a pepper species believed to have been domesticated 4000 years ago in the Andean region at the same time as $C$. chinense (Pickersgill, 2007). There are two genetic groups identified for the domesticated C. baccatum; i.e., those from the western region of South America consisting of accessions from Peru, Columbia, Ecuador, Bolivia, Chile, and Argentina and those from the eastern areas of Paraguay and eastern Argentina (Albrecht et al., 2011). C. annuum, a domesticate that is believed to have originated in the Mesoamerican region 6000 years ago according to archeological evidence (Perry et al., 2007), has also been shown to have a geographical structure to its diversity. For this species, three geographic patterns of genetic differentiation are observed: eastern Mexico, western Mexico, and the Yucatan Peninsula (AguilarMelendez et al., 2009).

Within each geographical region for $C$. chinense, there were often accessions from more than one phylogenetic cluster. For instance, the majority of accessions from the Lower Amazon region fell into phylogenetic Cluster $\mathrm{C}$ and some accessions fell into phylogenetic Cluster B. This could have been an artifact resulting from bird dispersal (Tewksbury and Nabhan, 2001) or anthropogenic effects, because Capsicum is a highly traded

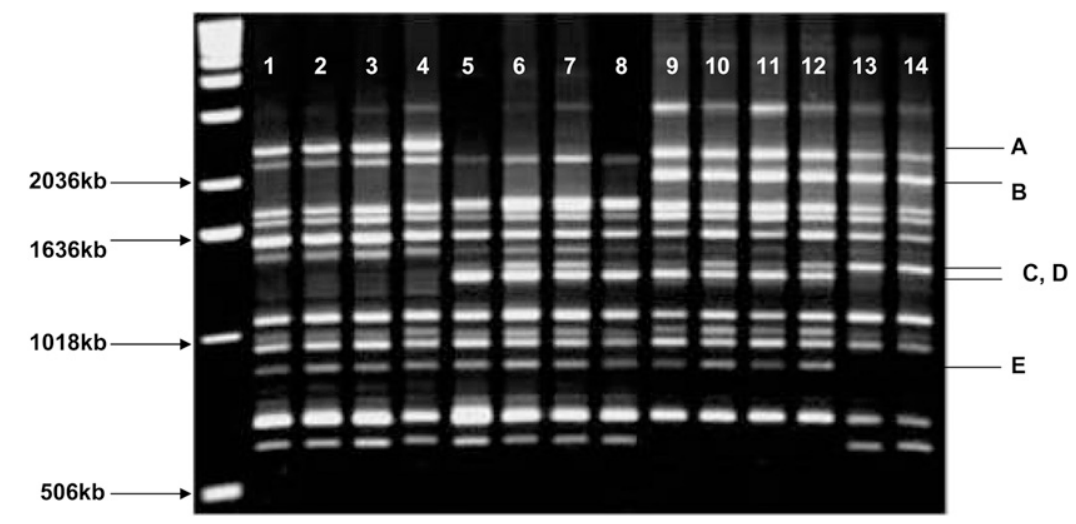

Fig. 1. Gel image showing random amplification of polymorphic DNA (RAPD) fragments amplified by Operon Primer OPRI2 (Operon Technologies, Alameda, CA) in 14 Capsicum chinense accessions (lanes 1-8 from the Upper Amazon, lanes 9-14 from the Lower Amazon region) on a 1.2\% agarose gel with 1-kb ladder (far left lane). The arrows represent fragment sizes, and letters A-F represent polymorphic (absence or presence) RAPD bands for the 14 accessions. commodity. To eliminate the effects of humans and/or bird dispersal, genetic diversity indices were calculated separately for each phylogeographic group (Table 4). The results indicate that the Lower Amazon accessions belonging to phylogenetic Cluster $\mathrm{C}$ and Upper Amazon accessions belonging to phylogenetic Cluster B had the greatest diversity estimates among the nine phylogeographical groups investigated. The fact that phylogenetic Cluster B, typical of the Upper Amazon, is the most widespread and the most variable in Latin America and the Caribbean supports previous reports (Eshbaugh, 1993; McLeod et al., 1982) that the Upper Amazon is probably the center of domestication of $C$. chinense.

The clear distinction between the Upper Amazon B and the Lower Amazon C, from continental South America, suggests that the dense Amazonian forest between these regions may have served as an effective barrier of panmixis. A similar divergence between cocoa populations from the Upper Amazon and Lower Amazon has also been reported (Motamayor et al., 2008).

Dispersion and the Likely origin of C. Chinense PHYLOGENETIC GROUPS. In C. annuum and C. baccatum, there is more genetic diversity in the wild forms than in the domesticates (Aguilar-Melendez et al., 2009; Albrecht et al., 2011) and this has been used to identify putative centers of diversity and domestication events. However, it is difficult to determine the wild forms of $C$. chinense as clearly as in the other domesticates (Eshbaugh, 1993) and there is believed to be no true form of wild C. chinense (Walsh and Hoot, 2001). However, by examining the history of the Latin America and the Caribbean region as revealed by archaeological studies, in conjunction with the data obtained in this and other studies, one can postulate possible dispersal paths for $C$. chinense within the Caribbean region.

Earliest archaeological records point to the existence of remains of $C$. annuum in Central America more than 6000 years ago and $C$. chinense in Peru $\approx 4000$ years ago (Perry et al., 2007), which supports the notion that $C$. chinense was domesticated in South America (Eshbaugh, 1993; McLeod et al., 1982; Pickersgill, 1971).

From historical descriptions, it is clear that Amerindians grew $C$. chinense in the Caribbean (Pickersgill, 2005; Rouse, 1993).

Table 2. Comparison of three diversity indices of Capsicum chinense within geographical regions in Latin America (Lower Amazon, Upper Amazon, Guianas including Venezuela, Central America) and the Caribbean (Greater Antilles, Lesser Antilles and Trinidad and Tobago).

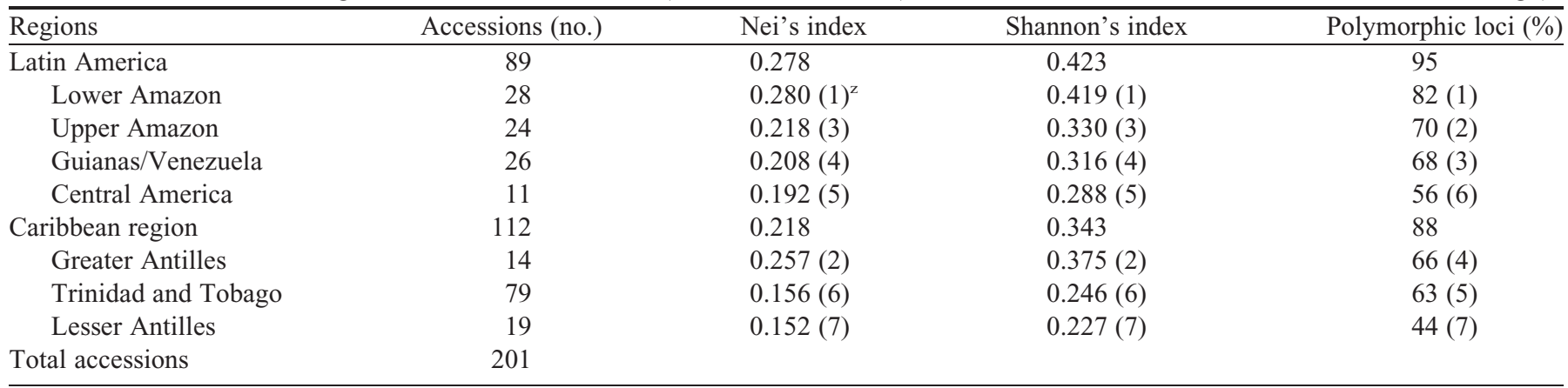

${ }^{\mathrm{z}}$ The numbers in parentheses refer to the numerical ranking of diversity in descending order. 


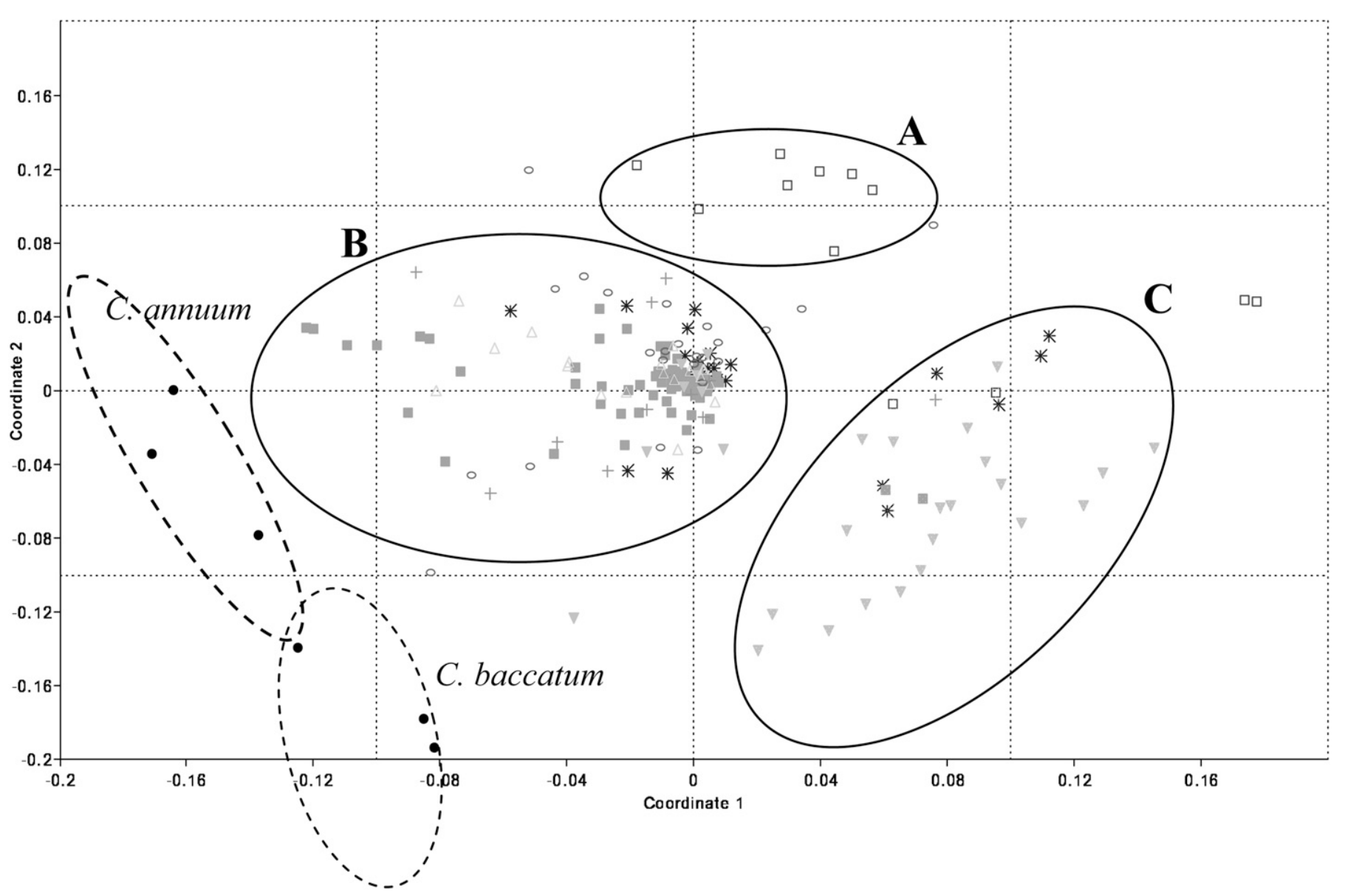

Fig. 2. Non-metric multidimensional scaling plot (MDS) showing the distinct clustering (Dice similarity index) of Capsicum chinense accessions from seven geographic regions ( ${ }^{*}$ Guianas including Venezuela, $\Delta$ Lesser Antilles, + Central America, $\square$ Greater Antilles, Upper Amazon, $\boldsymbol{\nabla}$ Lower Amazon, $\square$ Trinidad and Tobago) into three phylogenetic clusters, A, B, and C. Capsicum annuum and Capsicum baccatum accessions are indicated within the dotted lines.

Table 3. Analysis of molecular variation between three phylogenetic Clusters A, B, and C of Capsicum chinense.

\begin{tabular}{lrcrr}
\hline Source of variation & df & Sum of squares & Variance components & Variation (\% of total) \\
\hline Among populations & 2 & 317.502 & 4.79540 & 32.70 \\
Within populations & 188 & 1855.137 & 9.86775 & 67.30 \\
Total & 190 & 2172.639 & 14.66315 & $<0.05$ \\
\hline
\end{tabular}

Table 4. Genetic diversity estimates of Capsicum chinense within nine phylogeographical groups based on three diversity indices.

\begin{tabular}{|c|c|c|c|c|}
\hline Phylogeographic groupings & Accessions ( $\%$ of total $)$ & Nei's index & Shannon's index & Polymorphic loci (\%) \\
\hline Upper Amazon $\mathrm{B}^{\mathrm{z}}$ & 88 & $0.186(2)^{\mathrm{y}}$ & $0.282(2)$ & $61(3)$ \\
\hline Guianas B & 77 & $0.170(4)$ & $0.262(4)$ & $59(4)$ \\
\hline Trinidad and Tobago B & 97 & $0.157(6)$ & $0.248(5)$ & $63(2)$ \\
\hline Central America B & 82 & $0.176(3)$ & $0.262(3)$ & $49(5)$ \\
\hline Lower Amazon B & 29 & $0.147(8)$ & $0.218(8)$ & $41(8)$ \\
\hline Lower Amazon C & 71 & $0.272(1)$ & $0.406(1)$ & $78(1)$ \\
\hline Greater Antilles A & 60 & $0.164(5)$ & $0.241(6)$ & $44(7)$ \\
\hline
\end{tabular}

${ }^{\mathrm{z}} \mathrm{A}, \mathrm{B}$, and $\mathrm{C}$ denote phylogenetic clusters of Capsicum chinense.

${ }^{\mathrm{y}}$ The numbers in parentheses refer to the descending numerical order of diversity.

There are two plausible explanations for the presence of C. chinense, domesticated in the Upper Amazon, in the Antillean islands and Central America: 1) the dispersal of seeds by birds (Tewksbury and Nabhan, 2001) favored by south to north wind currents (Reid, 2009); or 2) deliberate transportation of the crop by the ancient migrating Amerindians.

Launching from the banks of the Orinoco River, it is suggested that Amerindians from South America first settled 
A Furthermore, the diversity measures for the phylogeographic groups within Cluster B indicate that the samples from the Upper Amazon were the most diverse followed by those in the Guianas including Venezuela, Trinidad and Tobago, and Lesser Antilles in that order. Frankham et al. (2002), based on a collation of many studies, showed that the diversity of species decreases away from the mainland. This supports a migratory route from the Upper Amazon through Guianas including Venezuela, into Trinidad and the Lesser Antilles islands. This migratory route is also supported by archaeological records of human migration as well as the avian migration model (Reid, 2009). The fact that phylogenetic Cluster B did not reach the Greater Antilles can also be explained by archaeological evidence that points to an Amerindian front resisting any migration from the Lesser Antilles into the Greater Antilles (Reid, 2009).

The significantly diminished variation of Central America B, compared with that for Upper Amazon B, suggests a second migratory route of $C$. chinense from the Upper Amazon to Central America. The Isthmus of Panama, a constriction, only $48 \mathrm{~km}$ at its narrowest point, which squeezes the American continent into South and Central America, is believed to have formed 3 million years ago (Duque-Caro, 1990). It has long been a matter of contention whether the Isthmus of Panama provided an efficient route of north-south dispersion of species between the mega centers, and if so, how effective a path it has been during the historical ages. Some (Myers, 1964) argue, that since the last recession of the cordilleran glaciers, the Isthmus has been covered by dense tropical forest and plagued by numerous tropical diseases creating an unwelcome environment for human habitation and hence an inefficient dispersion route. Others (Dickau et al., 2007) report evidence of dispersal of maize (Zea mays), manioc (Manihot esculenta), and arrowroot (Maranta arundinacea) through the Isthmus of Panama as early as $7000 \mathrm{CE}$. However, the significantly diminished diversity of $C$. chinense in Central America B suggests the Isthmus of Panama may have served as an inefficient dispersal path of $C$. chinense into Central America. Although other studies (Clement et al., 2010; Gepts and Bliss 1988; Vigouroux et al., 2008) postulate a path from Meso-America to South America through the Central American bridge for the Mesoamerican domestication complex [C. anпииm, wild beans (Phaseolus vulgaris), and maize], this study and archeological studies favor domestication in the Upper Amazon and a dissemination path in the opposite direction for $C$. chinense.

The origin of phylogenetic Cluster A that is peculiar to Greater Antilles is not clear. One could postulate an origin through recent hybridization of $C$. chinense with other cultivated Capsicum species indigenous to Mesoamerica such as $C$. annuum or C. frutescens that coinhabit the region (Bosland and Votava, 2000). Alternatively, in the absence of gene flow from mainland populations, small island populations may have undergone considerable genetic drift.

The third migratory route for $C$. chinense may have occurred from the Upper Amazon to the Lower Amazon in the distant past. Evidence for this comes from the existence of two phylogenetic Clusters, $\mathrm{B}$ and $\mathrm{C}$ in the Lower Amazon of which Cluster $\mathrm{C}$ is the dominant one ( $80 \%$ of accessions). This suggests that these Lower Amazon accessions may have become isolated from the main gene pool of the Upper Amazon, which may have led to the evolution of phylogenetic Cluster C. As mentioned previously, the Amazonian forests may have 
served as such a barrier that could have led to such genetic isolation. The presence of a few accessions typical of Cluster B may be a result of recent anthropogenic events. Alternatively, two separate domestication events may have founded the two populations.

IMPLICATIONS TO BREEDING. In this study, molecular markers were used to assess the genetic diversity within populations of $C$. chinense and to understand the genetic structure of populations. The presence of three phylogenetic clusters in the species indicates the potential of investigating interpopulation heterosis approaches in hybrid breeding. Furthermore, it is possible to concentrate complementary genes among the various phylogenetic clusters through reciprocal recurrent selection.

Molecular markers developed in this study will also assist in the effective management of collections of $C$. chinense by removing duplicates and establishing a core collection. In addition, molecular techniques aid the ability of researchers to determine the identity, purity, and stability of cultivars. This information can then be used to protect the rights of breeders and research institutions and to develop effective seed quality control programs (Ilbi, 2003). High-density genetic maps developed in the future can also allow the application of markerassisted selection in $C$. chinense.

\section{Literature Cited}

Aguilar-Melendez, A., P.L. Morrell, M.L. Roose, and S.C. Kim. 2009. Genetic diversity and structure in semiwild and domesticated chiles (Capsicum annuum; Solanaceae) from Mexico. Amer. J. Bot. 96:1190-1202.

Albrecht, E., D. Zhang, R.A. Saftner, and J.R. Stommel. 2011. Genetic diversity and population structure of Capsicum baccatum genetic resources. Genet. Resources Crop Evol. 59:517-538.

Baral, J. and P.W. Bosland. 2002. Genetic diversity of a Capsicum germplasm collection from Nepal as determined by randomly amplified polymorphic DNA markers. J. Amer. Soc. Hort. Sci. 127:318-324.

Baral, J.B. and P.W. Bosland. 2004. Unraveling the species dilemma in Capsicum frutescens and $C$. chinense (Solanaceae): A multiple evidence approach using morphology, molecular analysis, and sexual compatibility. J. Amer. Soc. Hort. Sci. 129:826-832.

Bosland, P. and E. Votava. 2000. Peppers: Vegetable and spice capsicums. CABI International, Wallingford, UK.

Buso, G.S.C., Z.P. de Sousa Amaral, L.B. Bianchetti, F.R. Borges, and M.E. Ferreira. 2003. Genetic variability and phylogenetic analysis of Brazilian species of Capsicum. Capsicum Eggplant Nwsl. 22:13-16. Clement, C.R., M. de Cristo-Araújo, G.C. d'Eeckenbrugge, A. Alves Pereira, and D. Picanço-Rodrigues. 2010. Origin and domestication of native Amazonian crops. Diversity 2:72-106.

Cooper, B., M. Gordon, and I. Ameen. 1993. Hotpepper production guide for Antigua. Caribbean Agricultural Research and Development Institute Publ., St. Augustine, Trinidad and Tobago.

Dickau, R., A.J. Ranere, and R.G. Cooke. 2007. Starch grain evidence for the preceramic dispersals of maize and root crops into tropical dry and humid forests of Panama. Proc. Natl. Acad. Sci. USA 104:36513656.

Duque-Caro, H. 1990. Neogene stratigraphy, paleoceanography and paleobiogeography in northwest South America and the evolution of the Panama Seaway. Palaeogeogr. Palaeoclimatol. Palaeoecol. 77:203-234.

Eshbaugh, W.H. 1993. Peppers: History and exploitation of a serendipitous new crop discovery, p. 132-139. In: Janick, J. and J.E. Simon (eds.). New crops. Wiley, New York, NY.

Excoffier, L., G. Laval, and S. Schneider. 2005. Arlequin ver. 3.11: An integrated software package for population genetics data analysis. Evol. Bioinform. Online 1:47-50.
Frankham, R., D.A. Briscoe, and J.D. Ballou. 2002. Introduction to conservation genetics. Cambridge University Press, New York, NY. Garcia, B., G. Salinas, C. Pozo, V. Reyes, M. Ramírez, S. López, B. Aguirre, and S. Salazar. 2002. Estimation of genetic distances among green pepper (Capsicum annuum L.) lines using RAPD markers and its relationship with heterosis. Proc. Intl. Pepper Conf. 16:10-12.

Geleta, L.F. and M.T. Labuschagne. 2004. Hybrid performance for yield and other characteristics in peppers (Capsicum annuum L.). J. Agr. Sci. 142:411-419.

Geleta, L.F., M.T. Labuschagne, and C.D. Viljoen. 2004. Relationship between heterosis and genetic distance based on morphological traits and AFLP markers in pepper. Plant Breed. 123:467-473.

Gepts, P. and F. Bliss. 1988. Dissemination pathways of common bean (Phaseolus vulgaris, Fabaceae) deduced from phaseolin electrophoretic variability. II. Europe and Africa. Econ. Bot. 42:86-104.

Guzmán, F.A., H. Ayala, C. Azurdia, M.C. Duque, and M.C. de Vicente. 2005. AFLP assessment of genetic diversity of Capsicum genetic resources in Guatemala: Home gardens as an option for conservation. Crop Sci. 45:363-370.

Hammer, Ø., D.A.T. Harper, and P.D. Ryan. 2001. PAST: Paleontological statistics software package for education and data analysis. Palaeontol. Electronica 4:9.

Hari, G.S., P.V. Rao, and Y.N. Reddy. 2005. Evaluation of paprika (Capsicum annuum L.) germplasm and its utility in breeding for higher yield and better quality grown under irrigated conditions. Res. Crops 6:266-269.

Heiser, C.B. 1976. Peppers Capsicum (Solanaceae), p. 265-268. In: Simmonds, N.W. (ed.). Evolution of crop plants. Longman Press, London, UK.

Hernandez-Verdugo, S., R. Luna-Reyes, and K. Oyama. 2001. Genetic structure and differentiation of wild and domesticated populations of Capsicum annuum (Solanaceae) from Mexico. Plant Syst. Evol. 226:129-142.

Hundal, J.S. and R.K. Dhall. 2005. Breeding for hybrid C. chinense. J. New Seeds 6:31-50.

Ilbi, H. 2003. RAPD markers assisted varietal identification and genetic purity test in pepper, Capsicum annuum. Sci. Hort. 97:211-218.

International Plant Genetic Resources Institute. 1983. Genetic resources of Capsicum: A global plan of action. International Board for Plant Genetic Resources, Rome, Italy.

Kang, B.C., K.T. Kim, D.S. Kim, and D.G. Oh. 1997. Random amplified polymorphic DNA analysis of Capsicum germplasm. J. Korean. Hort. Sci. 38:39-42.

Khalil, R.M., F.A. Ali, A.M. Metwally, and S.T. Farag. 2002. Breeding studies on pepper. Acta Hort. 637:161-168.

Lanteri, S., A. Acquadro, L. Quagliotti, and E. Portis. 2003. RAPD and AFLP assessment of genetic variation in a landrace of pepper (Capsicum annuum L.), grown in north-west Italy. Genet. Resources Crop Evol. 50:723-735.

Lee, J.M., S.H. Nahm, Y.M. Kim, and B.D. Kim. 2004. Characterization and molecular genetic mapping of microsatellite loci in pepper. Theor. Appl. Genet. 108:619-627.

Lefebvre, V., A. Palloix, and M. Rives. 1993. Nuclear RFLP between pepper cultivars (Capsicum annuum L.). Euphytica 71:189-199.

Loaiza-Figueroa, F., K. Ritland, J.A.L. Cancino, and S.D. Tanksley. 1989. Patterns of genetic variation of the genus Capsicum (Solanaceae) in Mexico. Plant Syst. Evol. 165:159-188.

McLeod, M.J., S.I. Guttman, and W.H. Eshbaugh. 1982. Early evolution of chili peppers (Capsicum). Econ. Bot. 36:361-368.

Motamayor, J.C., P. Lachenaud, J.W. da Silva e Mota, R. Loor, D.N. Kuhn, J.S. Brown, and R.J. Schnell. 2008. Geographic and genetic population differentiation of the Amazonian chocolate tree (Theobroma cacao L). PLoS One 3:E3311, DOI: 10.1371/journal.pone.0003311.

Myers, G.S. 1964. A brief sketch of the history of ichthyology in America to the year 1850. Copeia 1:33-41.

Panda, R.C., O. Aniel Kumar, and K.G. Raja Rao. 1986. The use of seed protein electrophoresis in the study of phylogenetic relationships in chili pepper (Capsicum L.). Theor. Appl. Genet. 72:665-670. 
Paran, I., E. Aftergoot, and C. Shifriss. 1998. Variation in Capsicum annuum revealed by RAPD and AFLP markers. Euphytica 99:167-173.

Patel, J.A., M.J. Patel, R.R. Acharya, A.S. Bhanvadia, and M.K. Bhalala. 2004. Hybrid vigor, gene action and combining ability in chili (Capsicum annuum L.) hybrids involving male sterile lines. Indian J. Genet. Breeding 64:81-82.

Perry, L., R. Dickau, S. Zarrillo, I. Holst, D.M. Pearsall, D.R. Piperno, M.J. Berman, R.G. Cooke, K. Rademaker, and A.J. Ranere. 2007. Starch fossils and the domestication and dispersal of chili peppers (Capsicum spp. L.) in the Americas. Science 315:986-988.

Pickersgill, B. 1971. Relationships between weedy and cultivated forms in some species of chili peppers (genus Capsicum). Evolution 25:683-691.

Pickersgill, B. 2005. Spices, p. 153-172. In: Prance, G.T. and M. Nesbitt (eds.). The cultural history of plants. Routledge, New York, NY.

Pickersgill, B. 2007. Domestication of plants in the Americas: Insights from Mendelian and molecular genetics. Ann. Bot. (Lond.) 100:925940.

Prince, J.P., V.K. Lackney, C. Angeles, J.R. Blauth, and M.M. Kyle. 1995. A survey of DNA polymorphism within the genus Capsicum and the fingerprinting of pepper cultivars. Genome 38:224-231.

Prince, J.P., Y. Zhang, E.R. Radwanski, and M.M. Kyle. 1997. A versatile and high-yielding protocol for the preparation of genomic DNA from Capsicum spp. (pepper). HortScience 32:937-939.

Reid, B.A. 2009. Myths and realities of Caribean history. University of Alabama Press, Tuscaloosa, AL.

Rodriguez, J.M., T. Berke, L. Engle, and J. Nienhuis. 1999. Variation among and within Capsicum species revealed by RAPD markers. Theor. Appl. Genet. 99:147-156.

Rouse, I. 1993. The Tainos: Rise and decline of the people who greeted Columbus. Yale University Press, New Haven, CT.

Sambrook, J. and D.W. Russell. 2001. Molecular cloning, a laboratory manual. 3rd Ed. Cold Springs Harbor Laboratory Press, New York, NY.
Stewart, V. 2003. Understanding the Caribbean hotpepper market. Caribbean Hot Pepper Ind. Wkshp. Charting the way forward Port of Spain, Trinidad and Tobago. Caribbean Agr. Res. Dev. Inst. Publ., St. Augustine, Trinidad. p. 14-22.

Tewksbury, J.J. and G.P. Nabhan. 2001. Seed dispersal: Directed deterrence by capsaicin in chilies. Nature 412:403-404.

Toquica, S., F. Rodríguez, E. Martínez, M. Cristina Duque, and J. Tohme. 2003. Molecular characterization by AFLPs of Capsicum germplasm from the Amazon department in Colombia. Genet. Resources Crop Evol. 50:639-647.

U.S. Department of Agriculture. 2012. GRIN taxonomy for plants. 11 Apr. 2012. <http://www.ars-grin.gov/cgi-bin/npgs/html/exsplist.pl>. Vigouroux, Y., J.C. Glaubitz, Y. Matsuoka, M.M. Goodman, J. Sánchez, and J. Doebley. 2008. Population structure and genetic diversity of new world maize races assessed by DNA microsatellites. Amer. J. Bot. 95:1240-1253.

Votava, E.J., J.B. Baral, and P.W. Bosland. 2005. Genetic diversity of chile (Capsicum annuum var. annuum L.) landraces from northern New Mexico, Colorado, and Mexico. Econ. Bot. 59:8-17.

Votava, E.J. and P.W. Bosland. 2001. Genetic diversity of Capsicum pubescens revealed via RAPD analysis. Capsicum Eggplant Nwsl. 20:60-63.

Walsh, B.M. and S.B. Hoot. 2001. Phylogenetic relationships of Capsicum (Solanaceae) using DNA sequences from two noncoding regions: The chloroplast atpB-rbcL spacer region and nuclear waxy introns. Intl. J. Plant Sci. 162:1409-1418.

Weiss, E.A. 2002. Spice crops. CABI International, Wallingford, UK. Yeh, F.C. and T.J.B. Boyle. 1997. Population genetic analysis of codominant and dominant markers and quantitative traits. Belg. J. Bot. 129:157.

Yi, G., J.M. Lee, S. Lee, D. Choi, and B.D. Kim. 2006. Exploitation of pepper EST-SSRs and an SSR-based linkage map. Theor. Appl. Genet. 114:113-130. 